\title{
Acquisition of Real Estate in Mexico by U.S. Citizens and American Companies
}

\author{
JORGE A. VARGAS*
}

\section{TABLE OF CONTENTS}

I. HISTORICAL BACKGROUND

A. Reasons Leading to the Imposition of Constitutional

Prohibitions Upon Foreigners and Foreign Legal Entities

Regarding Real Estate in Mexico

B. Content of this Article

II. THE "RESTRICTED ZONE" AND THE "PERMITTED ZONE” UNDER

MEXICAN LAW

A. The Restricted Zone and the Permitted Zone

B. Legal Notion of Real Estate Under Mexican Law................................. 300

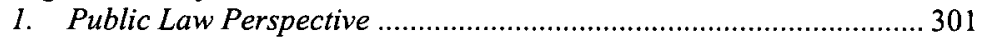

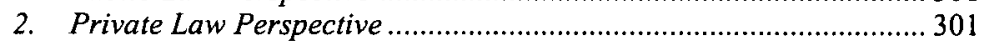

a. Immovable Assets Under Mexican Civil Law ............................ 302

* Professor of Law, University of San Diego School of Law. LL.B, summa cum laude, (Licenciado en Derecho), School of Law, National Autonomous University of Mexico, Mexico City; LL.M. and J.S.D. candidate, Yale Law School. Founder and Director of the Mexico-United States Law Institute, USD, 1983-1987. Guest Lecturer on Mexican Law at New York University School of Law, International Global Program (1999) and Visiting Professor at Stanford Law School (1994). Fulbright Border Lectureship Fellow (1998) and Fellow at the Center for U.S.-Mexican Studies, UCSD (La Jolla, 2000). Professor Vargas was a member of the Mexico City Bar Association and served as Legal Counsel to various agencies of the Government of Mexico from 1972 to 1982. The Author expresses his sincere thanks to Angela Dominguez (USD Class of 2008), Michael Paa (USD Class of 2008), and Jerry Gonzales (USD Class of 2008) for their excellent research assistance during the preparation of this Article. Mrs. Magali Garcia, the Author's assistant deserves thanks as well. The Author verifies the accuracy of the Spanish language cites and all of the English translations. Since 1994, Prof. Vargas has maintained a web site on Mexican law at http:// www.mexlaw.com. 
III. ACQUisition OF REAL ESTATE IN MEXICO BY U.S. CitizenS ............................. 304

A. Under Mexican Law, U.S. Nationals are Forced to

Enter into a Fideicomiso

1. The Mexican Fideicomiso: Legal Nature and Parties .................... 306

B. Today, Fideicomisos are Governed by Mexico's Foreign

Investment Act of 1993 and by Its 1998 Regulations

1. The Convenio or Mexican Version of the "Clásula

Calvo"

2. Fideicomisos for Residential Purposes ......................................... 312

3. Fideicomisos for Commercial Purposes ....................................... 314

IV. ACQUISITION OF REAL ESTATE FOR COMMERCIAL PURPOSES

BY AMERICAN COMPANIES.

A. Maximum Duration of Fideicomisos.................................................... 317

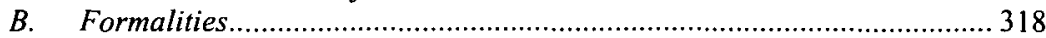

V. ACQuisition of Real Estate in the Permitted Zone ................................. 318

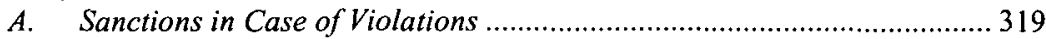

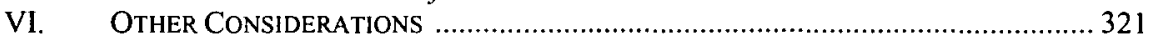

A. Required Involvement of a Mexican Notary Public ............................ 321

B. $\quad$ The Federal Maritime Land Zone ......................................................... 322

C. Questionable Validity of Article 27 Permit Under

International Law

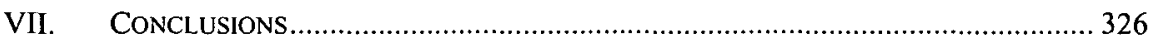

\section{HISTORICAL BACKGROUND}

\section{A. Reasons Leading to the Imposition of Constitutional Prohibitions \\ Upon Foreigners and Foreign Legal Entities \\ Regarding Real Estate in Mexico}

During the discussions at Mexico's Constitutional Congress held at the colonial city of Querétaro in 1916 to 1917 , one of the provisions ${ }^{1}$ that generated a heated debate was an article discussing two legal questions of the utmost importance at that time: first, Mexico's exercise of its national sovereignty over all natural resources; ${ }^{2}$ and, second, the legal capacity of individuals and legal entities to own lands and waters in the country. ${ }^{3}$

1. For the text of the Draft Constitution (Proyecto de Constitución) submitted by Venustiano Carranza to the National Constitutional Congress, see, LEYES FUNDAMENTALES DE MÉXICO 1808-1991, at 817 (16th ed. 1991).

2. Id. at 826 . The proposed Article 27 , one of the longest and most technical in the Draft Constitution, included questions pertaining to the Nation's right, at all times, to impose on private property any limitations demanded by public interest; the right to expropriate private property; the sovereign right over minerals and substances, including oil and hydrocarbons, lakes, rivers and waters; and other rights. Id.

3. See id. at 827 (displaying the text of Article 27, para. I, of the Draft Constitution in Spanish). 
When the new Federal Constitution was finally enacted on February 5 , 1917, the text of Article 27, paragraph I, read:

\begin{abstract}
Only Mexicans by birth or by naturalization and Mexican companies [or sociedades mexicanas] have the right to acquire ownership of lands, waters, and their accessions, or to obtain concessions for the exploitation of mines and waters. The State may grant the same right to foreigners provided they agree before the Secretariat of Foreign Affairs [or Secretaria de Relaciones Exteriores or SRE] to consider themselves as [Mexican] nationals with respect to said properties and not to invoke the protection of their governments in matters relating thereto; under penalty, in case of violation of the agreement [convenio], of forfeiting to the benefit of the Nation the properties they had acquired by virtue of said agreement. Under no circumstances may foreigners acquire ownership of lands or waters within a strip of one hundred kilometers for 64 miles] along the [international] borders and fifty kilometers [or 32 miles] along the coastlines. ${ }^{4}$
\end{abstract}

It is quite evident from the tenor of the preceding text that, at least since 1917, this constitutional prohibition - which establishes a clear discriminatory treatment of foreigners vis- $\dot{a}$-vis Mexicans-has been Mexico's most powerful legal policy influencing the property regime over real estate for more than seven decades. Accordingly, in order to maintain symmetry with this constitutional prohibition, the first Foreign Investment Act, enacted by Mexico's President Luis Echeverría Alvarez in 1973, strictly adhered to this prohibition, reproducing its language in several of its Articles. $^{5}$

The purpose of the 1917 constitutional prohibition and subsequent legislative enactments was to keep foreign nationals from owning real estate along the international border with the United States and along coastal areas. It was principally based on historical considerations. At that time, as a consequence of Mexico's tragic and bitter military

4. Constitución Política de los Estados Unidos Mexicanos [Const.], as amended, art. 27, Diario Oficial de la Federación [D.O.], 5 de Febrero de 1917 (Mex.) (emphasis added). The text of the original Article 27, para. I, of the Draft Constitution was adopted without changes. This text remains the same as of today (December 2006) notwithstanding that Mexico's Federal Constitution of 1917 continues to be in force, after it has been amended some 500 times. See LEYES FundaMENTALES DE MÉxICO 1808-1991, supra note 1.

5. See Ley para Fromover la Inversión Mexicana y Regular la Inversión Extranjera [L.P.I.M.] [Act to Promote Mexican Investment and Regulate Foreign Investment], arts. 7, 4, 5, 9, Diario Oficial de la Federación [D.O.], Marzo de 1973 (Mex.), translated in NATIONAL COMMISSION ON FOREIGN INVESTMENTS: JURIDICAL FRAMEWORK AND ITS APPLICATION 43-64 (1984). Article 7 of this Act reproduces the final paragraph of Article 27, para. I, of the Federal Constitution. Id. art. 7. 
experiences, foreign nationals from major powers were perceived as a real threat to the country's national territorial integrity and security.

During its early years as an independent nation, Mexico became engaged in military confrontations with the United States, Spain, France and England-not to mention a number of "private invasions" by filibusters usually supported and financed in secret by certain major powers. Most of these confrontations traced back to the strategic and steady flow of foreign immigrants to border and coastal areas in Texas, Alta and Baja California, New Mexico, Sonora, Chihuahua, Nuevo León and Tamaulipas. ${ }^{6}$ Indeed, the loss of Texas by Mexico to the United States may be considered the most successful model of this strategy commonly used by certain countries during the 19th century not only in the Americas but throughout the world and in particular in Africa, Asia and Oceania.

Writing in February of 1830 regarding the dangers of opening Mexico to foreign settlers who might colonize and populate the country (at that time virtually uninhabited but a geographically large and rich territory), Lucas Alamán, then Mexican Secretary of Foreign Affairs, warned:

They (the United States) start by introducing themselves into the land they are targeting, under the pretext of mercantile negotiations, or to establish colonies of the foreign government they represent by concessions or without them; these colonies grow, multiply, and then become the predominant part of the population, and when they have their support, they start to feign rights which are impossible to be recognized in any serious discussion, and they advance ridiculous claims based on historic facts that no one admits . . . 7

Additionally, during its early relations with the United States, from 18211845 , Mexico was a country in fear of the ambitious and expansionist policies advanced by the United States. The era was treacherous, filled with mutual distrust and no basis for friendship and cooperation between the two countries. César Sepúlveda summarizes the causes leading to the loss of Texas in these terms:

In essence, both nations did not trust each other, they feared each other, and it may be said that they hated each other at that time. Conspiring to create this situation included not only the differences of religion, culture, tradition and history but also a keen conflict of material interests and the fatidic and evil legend against Hispanics. From another angle, the Yankee's territorial appetite, enhanced by the 1819 acquisition, became exacerbated by having in front of it

6. In Mexico, the literature on this subject is prolific. See 2 LUIS G. ZORRILLA, Historia DE LAS RELACIONES ENTRE MÉXICO Y ESTADOS UNIDOS DE AMÉRICA 1800-1958 (2d ed.1977); ALBERTO MARÍA CARREÑo, MÉXICO Y EsTADOS UNIDOS DE AMÉRICA (2d ed. 1962); CÉSAR SEPÚl VEDA, INTEGRACIÓN Y DESINTEGRACIÓN DE LA FRONTERA NORTE (1978) [hereinafter SEPÚl VEDA, INTEGRACIÓN Y DESINTEGRACIÓN]; CÉSAR SEPÚlVEDA, LA FroNTERA NORTE DE MÉXICO: Historia, CONFLICTOS 1762-1975 (1976) [hereinafter SEPÚl VEDA, LA FRONTERA NORTE].

7. SEPÚlVEDA, LA FRONTERA NORTE, supra note 6, at 50. 
an uninhabited territory and a weak republic, sickened by politics and by its lack of unity. The coming blow was easy to anticipate. ${ }^{8}$

The military blow that epitomizes the worst act the United States inflicted upon Mexico is the unfair and often cited Mexican-American war of 1846 to 1848 . In that war, Mexico lost more than half of its national territory, comprised today by the current states of California and Arizona, as well as parts of Colorado, Nevada, New Mexico and Utah, as prescribed by the Treaty of Guadalupe Hidalgo of $1848 .^{9}$

In his message to Congress to report the end of the "war of conquest" against Mexico, President Polk proudly estimated that the newly acquired territory totaled over 851,598 square miles. $^{10}$ The Mexican sentiment associated with the Treaty of Guadalupe Hidalgo is expressed by Luis G. Zorrilla, diplomat and historian who has studied in detail the relations between both countries. He characterizes the treaty as "imposed to Mexico, as one of the harshest in modern history, if the World War II [treaties] are excepted, given the enormous extension of territory which was taken away from Mexico." 11

Accordingly, it is not strange or unusual, given the history of the numerous conflicts Mexico withstood from the United States-most of which resulted favorably to the United States-that our neighbor to the South developed a certain antagonism towards the United States. The presence of this antagonism is more evident when one reviews the history of the U.S.-Mexico bilateral relations. This is especially true when paying special attention to the territorial boundaries after Mexico's independence, the allocation and utilization of water resources, Mexican claims against the United States, political preferences during Mexico's

8. Id. at 47 .

9. Treaty of Peace, Friendship, Limits, and Settlement, U.S.-Mex., art. V, Feb. 2, 1848,9 Stat. 922.

10. See President James K. Polk, Fourth Annual Message (Dec. 5, 1848), in 6 A Compilation of the Messages and Papers of the Presidents 2483-84 (James D. Richardson ed., 1897).

11. ZORRILLA, supra note 6 , at 227. Regarding the $\$ 15$ million dollars the United States gave to Mexico "in consideration of the extension acquired ... by the United States," this author points out that the U.S. government, one generation prior to the Treaty of 1848, "used to sell the lands which it had obtained from the Indians at no less than $\$ 1.25$ per acre, which is close to $\$ 3.00$ U.S. dollars per hectare." According to Zorrilla, the territories lost by Mexico totaled some two million hectares. Based on this calculation, the sum the United States should have paid to Mexico was in the order of over half a billion dollars-or more exactly, $\$ 681,278,400$. See Jorge A. Vargas, Is the International Boundary Between the United States and Mexico Wrongly Demarcated?, 30 CAL. W. INT'L L.J. 215, 253 (2000). 
revolutionary times, national sovereignty over natural resources, and oil exploitation and expropriation questions, to mention but a few.

Given this historical background, and the political issues in the two countries, it was only natural that the Constitutional Congress of Querétaro was determined to include in the language of Mexico's fundamental law, the Federal Constitution of 1917, an outright prohibition banning foreigners from acquiring and owning real estate along Mexico's extended international boundaries and even longer and beautiful coastlines along the Baja California peninsula, the Pacific Ocean, the Gulf of California, the Gulf of Mexico, and the Caribbean Sea. ${ }^{12}$

In closing this historical section, it is indispensable to add that today the personal, business, and diplomatic relations between the countries are closer and friendlier than ever. When Sr. Lic. Felipe de Jesús Calderón Hinojosa took office as President of Mexico on December 1, 2006, it marked the anticipation of an era where Mexico and the United States would work together to forge new and stronger relations based on equality, pragmatism, international trends and, above all, full compliance with human rights and international law.

\section{B. Content of this Article}

Acquiring real estate in Mexico by foreigners may be one of the most cumbersome, costly and complicated processes of purchasing an immovable asset of anywhere in the world. The process is generally slow and involves a large number of participants: a notary public; a banking official in charge of the fideicomiso department at the local bank; the head of the Public Registry of Property and Commerce, Registro Público de la Propiedad y del Comercio; the local tax collector; a real estate appraiser; and the buyer's local counsel. All of these people are important because their direct involvement in the transaction is indispensable. No real estate transaction is safe, lawful or valid without any of them.

Buying real estate in Mexico, or enjoying the beneficiary rights through a real estate trust, known in Mexico as fideicomiso, involves a considerable amount of money and effort. One must take into account that this legal transaction is executed in Mexico in accordance with Mexican law-a foreign legal system belonging to the civil legal tradition, contrasted by the U.S. legal system derivative of the common law tradition-and recognize that Americans and U.S. legal entities are typically quite unfamiliar with Mexican law. This Article provides a

12. Mexico has the longest picturesque coastline of all the countries in Latin America, calculated at some 6,000 miles or approximately $10,000 \mathrm{~km}$. 
complete overview of the process of acquiring real estate in Mexico by Americans and U.S. companies in both the "Restricted Zone" and in the area situated outside the Restricted Zone, named here as the "Permitted Zone" for practical purposes.

\section{THE "RESTRICTED ZONE" AND THE "PERMITTED ZONE" UNDER MEXICAN LAW}

\section{A. The Restricted Zone and the Permitted Zone}

For purposes of acquisition of real estate by Americans whether individuals or companies, the territory of the Republic of Mexico-with an area ${ }^{13}$ about three times the size of Texas-is divided into two large areas: the Restricted Zone and the Permitted Zone. The Restricted Zone was originally named the "Prohibited Zone," Zona Prohibida, and is currently defined in the final part of paragraph one of Article 27 of the Federal Constitution as that "strip of one hundred kilometers along the [international] borders and fifty kilometers along the coastlines, where foreigners cannot acquire the direct ownership of lands and waters under any circumstances." Under Mexican law, the general interpretation of the preceding paragraph is as follows:

a) Only Mexicans by birth or by naturalization are allowed to have the right to directly own in fee simple a piece of real estate in that border or beach-front area;

b) Mexican companies with an "Exclusion of Foreigners Clause," Cláusula de Exclusión de Extranjeros, which means that no foreign nationals can be investors or partners in that company or Mexican legal entity, can also own in fee simple a piece of real estate located in that coastal or border area;

c) Although a U.S. citizen is constitutionally banned from having any real estate in that coastal area, Mexican law provides ${ }^{4}$ that a U.S. citizen may

13. Mexico's territorial area consists of $1,972,5000$ square kilometers, equivalent to 761,600 square miles. Mexico, in 24 THE NEW ENCYLOP EDIA BRITANNICA 27 (15th ed. 1998). Pursuant to the Federal Constitution, Mexico's "national territory comprises: I. The integral parts of the Federation [consisting of 31 States and one Federal District]; II. The islands' including reefs and keys in the adjacent seas; III. The islands of Guadalupe and Revillagigedos situated in the Pacific Ocean; IV. The continental shelf and the submarine shelves [or zócalos submarinos] of islands, keys and reefs; V. The waters of the territorial seas in the width and terms established by international law, and the internal waters; and VI. The superjacent space situated over the national territory to the extent and modalities established by international law." Constitución Política de los Estados Unidos Mexicanos [Const.], as amended, art. 42, Diario Oficial de la Federación [D.O.], 5 de Febrero de 1917 (Mex.).

14. See Ley de Inversión Extranjera [L.I.E.] [Foreign Investment Law], art. 10, Diario Oficial de la Federación [D.O.], 27 de Deciembre de 1993 (Mex.), translated in 
have the beneficiary rights over that piece of real estate in the Restricted Zone, provided it enters into a valid fideicomiso, a real estate trust contract for a period of fifty years, renewable for another fifty years; and

d) A Mexican company with U.S. foreign investment and U.S. partners or shareholders (i.e., a foreign legal entity, sociedad extranjera, incorporated in Mexico under Mexican law) is allowed to have the direct ownership in fee simple of a piece of land situated within that border or ocean-front property but only for commercial and industrial purposes.

The Restricted Zone includes the totality of the Baja California Peninsula, politically formed by two States: Baja California, in the northern part (capital in Mexicali, B.C.), and Baja California Sur (capital in La Paz, B.C. Sur). It has been estimated that the total area of the Restricted Zone in Mexico may comprise from 40 to $45 \%$ of that country's area. ${ }^{15}$ The Permitted Zone is Mexico's real estate area located outside the outer perimeter of the "Restricted Area," in the inland part of that country's land mass. ${ }^{16}$ Occasionally, determining whether a piece of real estate is located in the Restricted Zone or in the Permitted Zone may be a difficult task. In this regard, Article 6 of the 1989 Regulations to the Foreign Investment Act of 1993 reads: "In case of doubt whether an immovable asset is located within or outside the Restricted Zone, the Secretariat of Foreign Affairs in consultation with the National Institute of Statistics, Geography and Information [or Instituto Nacional de Estadistica, Geografia e Informática], shall resolve what is pertinent."

\section{B. Legal Notion of Real Estate Under Mexican Law}

Under Mexican law, property and ownership questions may be addressed from two different angles: public law and private law. Public law addresses issues affecting the interests of the Nation, res publica, as enunciated in the public policies advanced by the government. Private law involves questions regarding the personal interests of individuals.

33 I.L.M. 207 (1994). For purposes of this federal statute, the beneficiary rights of a U.S. citizen over a piece of real estate located in the Restricted Zone are legally defined as a "residential use" or $f$ in residencial. Id.

15. 1 JoRge A. VARGAS, Fideicomisos: Real Estate Trusts in Mexico's Restricted Zone, in MEXICAN LAW: A TREATISE FOR LEGAL PRACTITIONERS AND INTERNATIONAL INVESTORS 351, 361 (1998).

16. Id. at 362 . Interestingly, no official map has ever been published by the government of Mexico depicting either the Restricted Area or the Permitted Area.

17. Reglamento de la Ley de Inversión Extranjera y del Registro Nacional de Inversiones Extranjeras [Foreign Investment Regulations], art. 6, Diario Oficial de la Federación [D.O.], 8 de Septiembre de 1998 (Mex.). For additional information, see Jorge A. Vargas, Mexico's Foreign Investment Regulations of 1998, 23 Hous. J. INT'L L. $1,26(2000)$ 


\title{
1. Public Law Perspective
}

Accordingly, Mexico's Federal Constitution lists in Article 27 the public policies advanced by the Mexican State in matters of property and ownership. These policies govern the exploration, use and exploitation of natural resources belonging to the Nation, such as lands and waters, mineral deposits, solid mineral fuels, and petroleum and hydrocarbons. The Mexican State exercises direct and exclusive ownership in an inalienable manner over these resources and is not subject to any statute of limitations, el dominio de la Nación es inalienable e imprescriptible. The exploitation of these resources "cannot take place but through the issuance of concessions by the Federal Executive, in accordance with the rules and conditions established by the laws." 18

In this regard, Article 27 of the Federal Constitution is the source from which numerous federal statutes are derived-officially known as "Reglamentary Acts" or Leyes Reglamentarias. These statutes control and regulate, for example, the exploitation or utilization of oil, fishing, mining, forests, natural gas, certain rural areas, and radioactive minerals. Probably one of the most important considerations regarding private property is also found in Article 27. The pertinent paragraph reads:

\begin{abstract}
The Nation shall at all times have the right to impose on private property such limitations as the public interest may demand, as well as the right to regulate the utilization of natural resources which are susceptible to appropriation with the purpose of ensuring more equitable public wealth, taking care of their conservation, accomplishing a balanced development of the country, and the improvement of the living conditions of the rural and urban populations. Consequently, necessary measures shall be established for the ordering of human settlements and the adoption of adequate provisions ... the development of the small rural property; to preserve and restore the ecological balance; the promotion of agriculture, forestry and the other economic activities in the rural areas, and to avoid the destruction of the natural elements and the damage that property may suffer to the detriment of society. ${ }^{19}$
\end{abstract}

\section{Private Law Perspective}

All questions pertaining to property, possession and usufruct-that is, movable and immovable assets - are governed by the local Civil Code of the State where the real estate is located. In Mexico, the Civil Code is the center of a number of legal acts that take place on a daily basis

18. Constitución Política de los Estados Unidos Mexicanos, as amended, art. 27, Diario Oficial de la Federación [D.O.], 5 de Febrero de 1917 (Mex.) (emphasis added).

19. Id. 
principally between and among individuals. The provisions of this Code constitute the crux of private law, that is, the law that applies to the most essential rights and obligations of private citizens, including their relations with other individuals, as part of their personal and private affairs of life, in contrast to Public Law which regulates the general interests of the Nation.

The Civil Code, at the Federal and State levels, is divided into four books. In particular, Book Two, Property, governs real property, immovable assets, and personal property, movable assets, as well as possession-including adverse possession-ownership, usufruct, easements and prescription, that is the statute of limitations. ${ }^{20}$ This Code classifies assets or bienes into two large categories: (a) immovable assets, bienes inmuebles, also called bienes raices; and, (b) movable assets, bienes muebles. The classification is based on the mobility of the asset in question, and dates back to ancient Roman Law.

\section{a. Immovable Assets Under Mexican Civil Law}

Article 750 of the Federal Civil Code provides the following list of immovable assets or real property:

I. The ground and the construction attached to it;

II. The plants and trees, as well as the fruits on trees, while they are naturally joined to the earth and have not been cut as a crop, or otherwise severed;

III. Anything attached to realty in a permanent manner, so that upon separation a deterioration is caused to the realty of to the attached object;

IV. Statues, reliefs, paintings, or other ornamental objects placed on buildings or placed by the owner of the realty in such a way as to reveal an intent to unite them permanently to the estate;

V. Dovecotes, beehives, fish tanks or analogous breeding tanks, if the owner keeps them for the purpose of being integrated to the estate, and they form part of it in a permanent way;

20. See Código Civil Federal [C.C.F.] [Federal Civil Code], as amended, art. 750, Diario Oficial de la Federación [D.O.], 26 de Mayo de 1928 (Mex.), translated in JORGE A. Vargas, MeX. CIVIL CODE ANNotated (Bilingual ed. 2005). Book One refers to Persons and embraces questions relative to their domicile, civil registry, birth, marriage, divorce, death, and so forth. Book Three, titled Successions, includes successions by will, legal and testamentary, executors and partition questions. And Book Four covers Obligations including contracts, special obligations, mortgages, and others. For a more detailed description, see Jorge A. Vargas, The Federal Civil Code of Mexico, 36 INTERAM. L. REV. 229, 232 (2005). 
VI. Machines, containers, equipment and tools which the owner of the estate has destined for direct and exclusive industrial use or other exploitation of the estate;

VII. All fertilizers for agricultural crops of an estate, which are on the fields where they are to be used, as well as the necessary seeds for planting;

VIII. Electrical equipment and appliances and their accessories that are fixed to the ground or to a building by the owner, unless an agreement provides otherwise;

IX. All wells, pools, reservoirs and waterways, as well as aqueducts and piping ducts of any type used for carrying liquids or gases to an estate or their extraction therefrom;

$X$. All kinds of animals used for breeding on rustic land dedicated totally or partially to the raising of cattle, as well as those used for the performance of farm work, as long as they are employed for that purpose;

XI. Dry dock and similar constructions which, even if movable by floating, are kept stationary at a specific location of a river, lake or coast by reason of their use and purpose;

XII. All rights related to real property; and

XIII. Telephone and telegraph lines and permanently based radiotelegraph stations. $^{21}$

Property is personal, bienes muebles, either by its nature or by legal fiat. ${ }^{22}$ Property that can be moved from one location to another, either by its own locomotion or by an outside moving force is personal property by nature. ${ }^{23}$ Those obligations and choices of action whose object is personal property or amounts due as a result of an in personam claim, are personal property by legal fiat. ${ }^{24}$ Additionally, based on the nature of property according to its ownership, property is either in the public domain $^{25}$ or is privately owned. Article 772 of the Federal Civil Code reads:

21. C.C.F. art. 750 .

22. Id. art. 752 .

23. Id. art. 753.

24. Id. art. 754. Other examples of personal property may be found in Articles $755-63$.

25. Id. art. 766-71 (referring to property under public domain which is divided into three groups: (i) property for public use; (ii) property used for public services; and, (iii) property held as private property). 
[P]rivately held property is that property for which individuals hold full rights of ownership and where no one else can interfere without their consent or without their authorization, as required by law. 26

\section{ACQUISITION OF REAL ESTATE IN MEXICO BY U.S. CITIZENS}

Recent studies suggest that the presence of U.S. citizens in Mexico is becoming larger, more varied and more permanent. ${ }^{27}$ Based on the latest National Institute of Statistics, Geography and Information (INEGI) technical report, almost half a million Americans live in the Republic of Mexico today on a permanent or semi-permanent basis. ${ }^{28}$ Further, the Secretariat of Tourism reported that in 2005 some twenty million American tourists visited Mexico. ${ }^{29}$

Whether it is the lower cost of living, the more affordable housing, the warm weather, the relaxed pace of life, the varied and exquisite Mexican cuisine, the long and fascinating Mexican history, the magnificent colonial architecture and the majestic and monumental archeological sites, or the contrastingly rich and vibrant Mexican culture, more Americans are moving to Mexico every year. ${ }^{30}$ Real estate agents in the United States are projecting trends of higher migration to Mexico in the future. This is based on the fact that some 76 million U.S. baby boomers will reach retirement age within the next twenty years, a segment of the American population is becoming more economically affluent, and real estate prices in the United States are likely to continue to increase. ${ }^{31}$

Given the Mexican law peculiarities and complexities associated with the acquisition of real estate in Mexico by foreign nationals, it is important to review the legal and administrative aspects of this process, as they apply to U.S. citizens. The INEGI's report points out that the overwhelming majority of Americans living in Mexico are located in the

26. Id. art. 772.

27. See Jorge A. Vargas, Rights and Obligations of Americans in Mexico Immigration Law and Other Areas of Mexican Law, 42 U. RICH. L. REV. 839 (2008).

28. InSTITUTO NACIONAL DE ESTADíSTICA, GEOGRAFla E INFORMÁTICA [INEGI] [NATIONAL INSTITUTE OF STATISTICS, GEOGRAPHY AND INFORMATION], LOS EXTRANJEROS EN MÉXICO [FOREIGNERS IN MEXICO] (2007), http://www.inegi.gob.mx/prod_serv/contenidos/ espanol/bvinegi/productos/estudios/sociodemografico/ext_en_mex/extraen_mex.pdf.

29. Secretaria de Turismo [MEX. SECRETARIAT OF TOURISM], TURISMO DE INTERNACIÓN: VISITANTES INTERNACIONALES HACIA MÉXICO 2001-2005 [INTERNATIONAL TOURISM: INTERNATIONAL VISITORS TO MEXICO] (2006), http://datatur.sectur.gob.mx/ pubyrep/cargas_manuales/DE/TurIn05.pdf.

30. See Renata S. Ortiz, A Protectionist Past Meets the International Future: Acquiring Property as a Foreigner in Mexico's Restricted Zone (Dec. 2005) (unpublished paper on file with author); Alfredo Corchado \& Laurence Iliff, Little Americas Take Hold Across Mexico, More U.S. Citizens Putting Down Roots South of the Border, Dallas MORNING NEWS, Mar. 14, 2005, at Al.

31. See Angleynn Meya, Reverse Migration: Americans in Mexico, ProB. \& PROP., Jul.-Aug. 2004, at 57, 57. 
Mexican States contiguous to the United States, namely Baja California with 51,935 , Chihuahua with 32,275 , Tamaulipas with 31,670 , Sonora with 10,564 , Coahuila with 4606 , and Nuevo León with $373 .^{32}$

\section{A. Under Mexican Law, U.S. Nationals are Forced to Enter into a "Fideicomiso"}

Virtually as soon as the outright prohibition in Article 27 of the new Federal Constitution of Mexico was released in 1917, U.S. citizens and U.S. companies hired professionally skilled Mexican attorneys to circumvent its application to Americans. As indicated earlier, ${ }^{33}$ the policy enshrined in paragraph one of Article 27 of the Federal Constitution also provided the substance of the legal framework applicable to foreigners in Mexico's first Foreign Investment Act of $1973 .{ }^{34}$ All kinds of fraudulent schemes-euphemistically referred to as "anomalous arrangements"-were attempted, ranging from complicated pyramidal structures for Mexican companies to exclusive private clubs in ocean-front properties to the "direct acquisition" through the so-called name lenders or prestanombres. ${ }^{35}$

After more than half a century of these fraudulent schemes, 19171970 , the thousands of ocean-front properties in Mexico was intolerable. ${ }^{36}$ Thousands of Americans and American companies continued to be interested, if not in owning, at least in enjoying a beautiful villa or condominium in a Mexican coastal area. Additionally, these "acquisitions" represented a substantial source of U.S. investment and translated into an increasing flow of American-dollar revenues for Mexico. As such, the Mexican government decided to use the newly introduced notion of the fideicomisoin reality a U.S. real estate irrevocable trust contract - as the legal tool to

32. INEGI, supra note 28 , at 19.

33. See supra pt. I.

34. See supra note 5 and accompanying text.

35. The prestanombres arrangement was the most common. Basically, a U.S. citizen, or a U.S. company, paid a Mexican national by birth to appear as the sole and lawful owner of the beach-front propefty in question. In reality, the American national, or the U.S. company, was the real owner of the property in question. Many Americans lost their beach-front properties this way when the Mexican nationals reneged on the arrangement and decided to take physical and legal possession of those properties.

36. For a roundtable discussion on the benefits of using the fideicomiso as the lawful instrument allowing Americans to invest in ocean-front properties-at that time called Prohibited Zones or Zonas Prohibidas, now known as real estate in the Restricted Zone-see LOS FIDEICOMISOS SOBRE INMUEBLES SITUAdOS EN ZONAS PROHIBIDAS [Proceedings of THE Round Table Discussion], Instituto MEXiCano DE DERECHO INTERNACIONAL PRIVADo [MEXICAN INSTITUTE OF PRIVATE INTERNATIONAL LAW] (1972). 
capitalize on these U.S. investments. On April 29, 1971, Lic. Luis Echeverría, then President of Mexico, signed a presidential agreement allowing Mexican banks and credit institutions to acquire the direct ownership of immovable assets, bienes inmuebles or bienes raices, located along the international borders and coastlines as fiduciaries, so that these real estate properties could be utilized by foreigners in industrial and tourists activities. $^{37}$

\section{The Mexican Fideicomiso: Legal Nature and Parties}

In general, fideicomisos provide individual foreign investors with a legal and practical avenue, allowing them to acquire not the direct ownership but, instead, only the beneficiary use, of a piece of real estate located within Mexico's Restricted Zone for a renewable period of fifty years. Imagine an American retiree, Mr. Smith, is interested in living in a beautiful ocean-front area in the outskirts of the city of Ensenada, Baja California, situated some thirty miles south of the U.S.-Mexico Port of entry in San Ysidro, California. The property in question is lawfully owned in fee simple by Señor Pérez. Mr. Smith and Señor Pérez agree on a price for that piece of real estate. Using the fideicomiso system, and after all the necessary legal and administrative arrangements, Mr. Smith pays Señor Pérez the price agreed for the enjoyment of beneficiary rights over the ocean-front property. Then, Señor Pérez transfers the property to a Mexican banking institution expressly authorized by the Mexican government- the Secretariat of Foreign Affairs (SRE)-to conduct this kind of transaction. In turn, the banking institution holds the title of the property in question during the duration of the fideicomiso contract, in general, a maximum of fifty years. Mr. Smith pays a fee to the banking institution for this service, and any other additional fees for services specifically requested by Mr. Smith, such as paying the local and federal taxes, utilities, and so forth.

Being a foreign national, Mr. Smith is expressly prohibited under Mexican law to directly own a piece of ocean-front property in the Restricted Zone, as mandated by paragraph one of Article 27 of Mexico's Federal Constitution. Therefore, in order to continue to attract American individual

37. See Acuerdo que Autoriza a la Secretaría de Relaciones Exteriores para conceder a las Instituciones nacionales de crédito, los permisos para adquirir como Fiduciarios el dominio de Bienes Inmuebles destinados a la realización de Actividades Industriales o Turísticas, en Fronteras y Costas [Agreement Authorizing the Secretary of Foreign Relations to Grant to the National Institutions of Credit the Permission to Acquire like Fiduciaries the Dominion of Industrial or Tourist Real Estate in Border and Coastal Areas], Diario Oficial de la Federación [D.O.], 30 de Abril de 1971. This enactment entered into force the same day. For additional information, see VARGAS, supra note 15 , at 353 . 
investors to the long and beautiful Mexican coastlines and border areas in the Restricted Zone, President Echeverría took advantage of the U.S. real estate trust contract and adapted it to the Mexican legal environment. In that way, he was able to provide a lawful and practical avenue for Americans to enjoy an ocean-front or an international border property for a considerable period of time. ${ }^{38}$

Retrospectively, opening of the ocean-front and international border properties to foreign investors, both individuals and companies took place in a gradual manner. This process was accomplished through the enactment of these four pieces of federal legislation: (a) the Federal Investment Act of 1973 enacted by President Echeverría; (b) the delayed publication of the "Regulations" to the 1973 Act, published in the Diario Oficial in 1989 during the administration of President Carlos Salinas de Gortari; (c) the Federal Investment Act of 1993, which reiterated and expanded the 1989 Regulations and was also enacted by President Salinas; and (d) the 1998 Regulations to the 1993 Foreign Investment Act published by President Ernesto Zedillo. ${ }^{39}$

Although originally introduced as a part of Mexican law in 1924, it was not until 1932 when the first General Act of Credit Instruments and Transactions recognized the fideicomiso as a valid, autonomous legal transaction. The current Credit Instruments Act defines fideicomisos this way: "By means of a fideicomiso, the fideicomitente [or trustor] transfers to a fiduciary institution the ownership or the title over one or more assets or rights, as may be the case, to be destined to a licit and determined objective, trusting a fiduciary institution [or fiduciaria] with the undertaking of such an objective. $40 "$

38. Originally, when the fideicomiso made its appearance in Mexico in 1971, these real estate trust contracts were given for a maximum period of thirty years. The period of time was later extended to fifty years to be renewed for an additional period of fifty years under certain conditions. See Ley de Inversión Extranjera [L.I.E.] [Foreign Investment Law], art. 10, Diario Oficial de la Federación [D.O.], 27 de Deciembre de 1993 (Mex.). See also Reglamento de la Ley de Inversión Extranjera y del Registro Nacional de Inversiones Extranjeras [Foreign Investment Regulations], art. 12, Diario Oficial de la Federación [D.O.], 8 de Septiembre de 1998 (Mex.).

39. For a detailed discussion of each of these federal enactments, see VARGAS, supra note 15 , at $126-37,357-73$.

40. Ley General de Títulos y Operaciones de Crédito [L.G.T.O.C.] [General Act of Credit Instruments and Transactions], as amended, art. 381, Diario Oficial de la Federación [D.O.], 27 de Agosto de 1923 (Mex.). Articles 381-406 regulate the different types of fideicomisos. Id. arts. 381-406. 
All fideicomisos must always be in writing, and they may apply to rights as well as assets. When they involve assets, the fideicomiso must be recorded at the Public Registry of Property and Commerce or Registro de la Propiedad y del Comercio of the place where the asset is located. This produces legal effects against third parties from the moment of recordation. Fideicomisos established to defraud third parties may be attacked as null and void by the interested parties. ${ }^{41}$

Accordingly, there are three parties to a fideicomiso, namely:

1) The fideicomitente (trustor) ${ }^{42}$ This party is the Mexican national or Mexican legal entity who owns the real estate which is the object of the trust contract. This party creates the fideicomiso by a personal, unilateral act. If the party does not reserve the right to revoke the fideicomiso at the act of establishment, then the trust contract is understood to be irrevocable. However, all of the fideicomisos affecting immovable assets are expressly stated to be irrevocable.

2) The fiduciario or fiduciaria (trust company or fiduciary institution). This must be an expressly authorized fiduciary institution in accordance with the law. ${ }^{43}$ Legally, the Mexican banking institution holds the legal title of the real estate "in trust" for the benefit of the foreign investor, performing its function in good faith. More importantly, it must faithfully comply with the obligations established by the trust contract and provide a clear and objective accounting to the other two parties regarding the operation of the fideicomiso. As is customary in these cases, the fiduciary institution will be liable for any losses or for any damage suffered by the real estate resulting from negligence or fault. The content of the trust contract is considered to be confidential and, as such, the fiduciary institution may only provide information regarding the fideicomiso to the corresponding parties and to the National Banking Commission. ${ }^{44}$

3) The beneficiary (trustee). This party is the American national or American company who is to enjoy the "beneficiary rights" with respect to the real estate located within the Restricted Zone. These benefits last for a maximum period of fifty years pursuant to the 1998 Regulations to the Foreign Investment Act

41. Id. arts. 386-88.

42. Id. art. 384 .

43. Id. art. 385 .

44. Id. art. 391 . 
of $1993 .^{45}$ Evidently, the beneficiaries' rights depend directly on the will and words of the trustor.

Some of the principal rights conferred upon the beneficiaries include, inter alia, the right to use and enjoy the property, the right to the fruits or income generated by the property, and the right to dispose of the property by gift, sale, or will. Other rights may address the right to demand that the property be delivered to them, the right to name or designate other beneficiaries, the right to remove the fiduciary institution, and the right to give or cease its beneficiary rights. Additionally, pursuant to the current General Act of Credit Instruments and Transactions, fideicomisos may be terminated by: (a) the complete realization of the specific objective enunciated in the trust contract; (b) the impossibility of reaching the trust contract's major objective; or (c) agreement of the parties. ${ }^{46}$

\section{B. Today, Fideicomisos are Governed by Mexico's Foreign Investment Act of 1993 and by Its 1998 Regulations}

Since 1973, fideicomisos in the Republic of Mexico involving real estate by foreigners have been governed by the Foreign Investment Act of $1993^{47}$ and the corresponding Regulations. ${ }^{48}$ In this regard, the pertinent language of Article 10, paragraph II, of that Act reads:

Pursuant to what is prescribed by paragraph one of Article 27 of the Political Constitution of the United Mexican States, Mexican companies with an "Exclusion of Foreigners Clause" or those who have entered into the agreement [or convenio] referred to in said Article, may acquire the ownership [or dominio] of immovable assets in the national territory.

In the case of companies [or sociedades] whose by-laws include the convenio prescribed in paragraph one of Article 27 of the Constitution, the following shall apply:

45. Reglamento de la Ley de Inversión Extranjera y del Registro Nacional de Inversiones Extranjeras [Foreign Investment Regulations], art. 12, Diario Oficial de la Federación [D.O.], 8 de Septiembre de 1998 (Mex.).

46. For a complete list of termination grounds, see L.G.T.O.C. art. 392.

47. Ley de Inversión Extranjera [L.I.E.] [Foreign Investment Law], Diario Oficial de la Federación [D.O.], 27 de Deciembre de 1993 (Mex.).

48. The Regulations were published in the Diario Oficial of September 8, 1998 and also regulate the National Registry of Foreign Investments (Registro Nacional de Inversiones Extranjeras). 
II. May acquire rights [or derechos] over immovable assets in the Restricted Zone to be destined to residential purposes [or fines residenciales], in accordance with the provisions of the following chapter. ${ }^{49}$

\section{The Convenio or Mexican Version of the "Clásula Calvo"}

In Mexico, this convenio or agreement is also commonly referred to as the "Special Permit of Article 27, paragraph one, of the Constitution" or Permiso especial Articulo 27 de la Constitucion to be issued by the SRE.

Regardless of the physical location of the real estate property of interest to a foreign investor whether in the Restricted Zone or in the Permitted Zone, the American individual or foreign legal entity must enter into this convenio, whose legal content requires the following:

(a) The American individual or American company is to consider himself a Mexican national with respect to any legal questions pertaining to the real estate;

(b) Explicitly recognize not to invoke the protection of his government in any matters pertaining to said real estate;

(c) Under penalty, in case of violation of this convenio, of forfeiting to the benefit of the Mexican nation the real estate acquired by virtue of the agreement.

In other words, under Mexican law today, no foreigner or foreign legal entity is legally allowed to have the direct ownership of real estate property anywhere in that country unless the foreign national or foreign legal entity executes with the SRE (either in person or through duly authorized legal counsel) the convenio expressly mandated by the Federal Constitution. This is a conditio sine qua non imposed by the Constitution, and compliance with the agreement is implemented and supervised by the SRE in a direct and exclusive manner.

Furthermore, the Federal Constitution states that granting this right to foreigners is subject to SRE's absolute discretion. As such, one may validly assume that the SRE is legally empowered to deny this right to any foreigner if the SRE determines such denial to be in Mexico's public interest. In this regard, Article 14 of the 1993 Foreign Investment Act prescribes the following: "The Secretariat of Foreign Affairs shall resolve regarding the permits to which this Chapter refers to taking into

49. L.I.E. art. 10 
consideration the economic and social benefit that said operations imply for the Nation." 50

Any application for a permit shall be resolved by the SRE within the five working days following the date of submission before the competent central administrative unit, or within the subsequent thirty working days, if submitted in the SRE state delegations. If these period of time has elapsed without having a resolution, the corresponding application is deemed approved. ${ }^{51}$

This clearly demonstrates the crucial role SRE plays in monitoring and supervising the application of this important constitutional provision. The SRE has the power to grant authorizations or permits in the following cases:

1. To incorporate a Mexican mercantile company in that country; ${ }^{52}$

2. To incorporate a Mexican mercantile company whose by-laws do not include an "Exclusion of Foreigners Clause;" "53

3. To establish a fideicomiso involving immovable assets (i.e., real estate) located within the Restricted Zone;

4. For a foreign individual to establish a fideicomiso involving real estate outside the Restricted Zone, that is in the Permitted Zone;

5. To establish a fideicomiso involving a neutral investment; ${ }^{54}$

6. For a foreign individual to obtain concessions for the exploration and exploitation of mines and waters outside the Restricted Zone;

7. For a credit institution (i.e., bank) to serve as a fiduciary in a fideicomiso involving real estate in the Restricted Zone;

8. Once incorporated, for a Mexican mercantile company to change its name or legal denomination, denominación o razón social;

9. For foreign legal entities, personas morales extranjeras, to conduct business in Mexico. ${ }^{55}$

50. L.I.E. art. 14 (emphasis added).

51. Id. The implied approval to which the final part of this Article refers to is known in Mexico as afirmativa ficta (implied or tacit approval).

52. L.I.E. art. 15.

53. An Exclusion of Foreigners' Clause, Cláusula de Exclusión de Extranjeros, is an explicit provision included in the by-laws of a Mexican company whereby it expressly states that the company does not have, and shall not ever have, foreigners or any foreign investment in it, as recorded by the corresponding Notary Public.

54. See L.I.E. arts. 18-22.

55. Id. art. 17. 


\section{Fideicomisos for Residential Purposes}

The 1993 Foreign Investment Act introduced a new classification system to categorize real estate uses by foreign nationals or foreign legal entities: (i) residential uses; and (ii) non-residential uses. ${ }^{56}$

The Foreign Investment Act Regulations of 1998 define a piece of real estate for residential purposes or fines residenciales as an immovable asset devoted exclusively to use as a residence or dwelling of the owner of the real estate or that of third parties. ${ }^{57}$ Examples of residential uses include:

I. Real estate destined to timeshares;

II. Those destined to some industrial, commercial or tourism activity;

III. Those acquired by credit institutions, financial brokers and credit auxiliary organizations;

IV. Those utilized by legal entities to fulfill its social objective (objeto social) which may consist of the alienation, urbanization, construction, lotification and other activities involved in the development of real estate projects until they become commercial or are sold to third parties; and

V. In general, real estate projects destined to commercial, industrial, agricultural, livestock, fishing, forestry and for rendering of services. $^{58}$

Foreign individuals interested in real estate in the Restricted Zone can only aspire to have beneficiary rights conferred to them by means of a fideicomiso. In other words, American individuals cannot have the direct ownership or fee simple ownership in the Restricted Zone because this is explicitly banned by Article 27, paragraph one, of the Federal Constitution. ${ }^{59}$ Article 9 of the 1998 Foreign Investment Act Regulations reads:

56. L.I.E. art. 10, para. I refers to the ownership of real estate, bienes inmuebles, located in the Restricted Zone, "destined to the realization of non-residential activities," actividades no residenciales, and impose the obligation to report the acquisition of the real estate to the SRE within sixty days working after the acquisition takes place. And L.I.E. art. 10, para. II refers to immovable assets in the Restricted Zone "to be destined to residential purposes," Fines residenciales.

57. Reglamento de la Ley de Inversión Extranjera y del Registro Nacional de Inversiones Extranjeras [Foreign Investment Regulations], art. 5, Diario Oficial de la Federación [D.O.], 8 de Septiembre de 1998 (Mex.).

58. Id. art. 5.

59. L.I.E. arts. 11-14. These Articles establish the requirements needed in this case, as complemented by Articles $9-12$ of the respective Regulations. Id.; Reglamento de la Ley de Inversión Extranjera y del Registro Nacional de Inversiones Extranjeras arts. 9-12. 
The applications submitted by the credit institutions, through their fiduciary delegate, to obtain the permit referred to in Article 1, of the Foreign Investment Act, should contain:

I. Name and nationality of the trustor and the beneficiary;

II. Name of the credit institution serving as fiduciary;

III. Name and nationality of the beneficiary [or fideicomisario] and, of the beneficiaries in the second degree [if any], and of the substitute beneficiaries;

IV. Duration of the fideicomiso;

V. Use of the real estate;

VI. Description, location and area of the real estate object of the fideicomiso; and

VII. Distance of the real estate from the Federal Maritime Land Zone (Zona Federal Maritimo Terrestre). ${ }^{60}$

The Regulations regulate in great detail the fideicomisos established pursuant to Article 11 of the Foreign Investment Act. Article 11 describes the special permit from the SRE which is required "for credit institutions to acquire as fiduciaries rights over immovable assets located within the Restricted Zone when the object of the fideicomiso is to allow the use and utilization of said assets without constituting rights in rem [or derechos reales] over them." ${ }^{61}$ Fideicomisos are of two kinds. There are those issued for Mexican companies without the Exclusion of Foreigners Clause in the case of Paragraph II of the Foreign Investment Act, and there are those issued for foreign individuals or foreign legal entities. In these particular cases, the Regulations mandate that the fideicomiso contracts must comply with the following conditions:

I. That the corresponding notarial instrument includes and imposes the Calvo clause, with all its legal implications;

II. That during the life of the fideicomiso the fiduciary institution continues to hold the title of the immovable asset in question;

III. That the fiduciary institution present to the SRE an annual report listing all the fideicomisos authorized by said institution

60. Reglamento de la Ley de Inversión Extranjera y del Registro Nacional de Inversiones Extranjeras art. 9. The application must be accompanied by the corresponding blueprint with measurements and boundaries of the piece of real estate. Id.

61. L.I.E. art. 11. 
during the preceding year, and the full compliance with the fideicomiso objectives;

IV. To obtain express authorization from the SRE to make any changes or modifications in the fideicomiso;

V. To notify SRE when the fideicomiso is terminated, among other things. ${ }^{62}$

\section{Fideicomisos for Commercial Purposes}

Article 10 of the 1998 Foreign Investment Act Regulations specifically addresses fideicomisos involving ocean-front properties and international border real estate that is within the Restricted Zone as prescribed by Article 11 of the 1993 Foreign Investment Act. In dealing with foreign individuals or foreign legal entities, personas fisicas o morales extranjeras, the SRE is required to grant the permits referred to in Article 11 of the Act when the application complies with the requirements enunciated by Article 9 of the Regulations ${ }^{63}$ and when the real estate in question which is the object of the fideicomiso is destined to be one of the following:

I. Industrial parks and industrial land developments [or fraccionamientos industrials];

II. Hotels and motels;

III. Industrial shells;

IV. Commercial centers;

V. Research centers;

VI. Tourism developments, provided they do not include immovables destined to be residential activities;

VII. Marinas for tourism purposes;

VIII. Docks and industrial and commercial installations established therein; and

IX. Establishments for the production, transformation, packing, conservation, transport or storage of agricultural, livestock, forestry and fishing products. ${ }^{64}$

62. Id.

63. For the requirements established by Article 9 of the Regulations, see supra note 60 and accompanying text.

64. Reglamento de la Ley de Inversión Extranjera y del Registro Nacional de Inversiones Extranjeras art. 10. 


\section{ACQUISITION OF REAL ESTATE FOR COMMERCIAL PURPOSES BY AMERICAN COMPANIES ${ }^{65}$}

Article 10 of Mexico's Foreign Investment Act of 1993 is endowed with profound legal significance. In the most unprecedented change of policy in the long legislative history of that country, this Article expressly asserts that American companies who have entered into a special Convenio Article 27, paragraph one or cláusula calvo with the SRE, "may acquire the direct ownership [or dominio] of real estate" anywhere in Mexico's national territory, including the Restricted Zone. The specific language of Article 10, paragraph I, reads:

In the case of companies [or sociedades] whose by-laws include the convenio prescribed in paragraph one of Article 27 of the Federal Constitution, the following shall apply:

I. [The companies] shall acquire the direct ownership [or dominio] of immovable assets located in the Restricted Zone, destined to the realization of non-residential activities, reporting said acquisition to the Secretariat of Foreign Affairs within the sixty working days following the date when the acquisition took place; and

II. [The companies] may acquire rights [or derechos] over immovable assets in the Restricted Zone to be destined to residential purposes [or fines residenciales], in accordance with the provisions of the following chapter. ${ }^{66}$

Evidently, based on the literal interpretation of these two paragraphs of the current Foreign Investment Act of 1993, foreign legal entities, that is American companies, are today legally authorized to invest in and have the direct ownership of ocean-front and border real estate provided: (a) that these foreign companies agree by means of a special convenio with SRE to be considered and treated as a Mexican national regarding

65. In reality, art. 10, para. I, of the Foreign Investment Act of 1993 regulates the manner in which foreign legal entities, sociedades extranjeras, may acquire the direct ownership of immovable assets in the national territory including the Restricted Zone in conformity with Article 27, Paragraph One of the Federal Constitution, when the real estate "is destined to the realization of non-residential activities" as explained in supra note 56 and accompanying text. L.I.E. art. 10. In Spanish, the Article reads "I. Podrán adquirir el dominio de bienes inmuebles ubicados en la Zona Restringida, destinados a la realización de actividades no residenciales." Id.

66. L.I.E. art. 10 (emphasis added). 
the ocean-front property; and (b) that the real estate in question is to be devoted to commercial or industrial activities.

At first sight, these two paragraphs appear to be in complete contradiction with the constitutional text in Article 27, paragraph one. That provision mandates that "[o]nly Mexicans by birth or by naturalization and Mexican companies have the right to acquire ownership of lands, waters and their accessions." ${ }^{.67}$ Additionally, at the end of the same paragraph, there is an even more stringent warning that "[u]nder no circumstances may foreigners acquire ownership of lands and waters" within the Restricted Zone. ${ }^{68}$ Within this narrow reading, it would be logical to conclude that Article 10 of the Foreign Investment Act is unconstitutional. ${ }^{69}$

However, reaching that conclusion would be incorrect. There are powerful reasons of convenience far more important than mere technical legal reasons. For decades, Mexico has been a country that has overwhelmingly depended upon the United States for economic support. As of early 2007, the amount of accumulated investment of the United States in Mexico from 1994 until 2006 was over $\$ 114$ billion dollars. ${ }^{70}$ With this amount of U.S. investment, the United States provided $62.6 \%$ of all direct foreign investments as of June $2006 .^{71}$ Furthermore, since the enactment of the Foreign Investment Act of 1993, most U.S. investment has taken place along the international border with the United States and in coastal areas in Mexico's Restricted Zone. ${ }^{72}$

67. Constitución Política de los Estados Unidos Mexicanos [Const.], as amended, art. 27, Diario Oficial de la Federación [D.O.], 5 de Febrero de 1917 (Mex.).

68. Constitución Política de los Estados Unidos Mexicanos [Const.], as amended, art. 27, Diario Oficial de la Federación [D.O.], 5 de Febrero de 1917 (Mex.).

69. For a discussion of this issue, see VARGAS, supra note 15 , at 111.

70. See COMISIÓN NACIONAL DE INVERSIONES EXTRANJERAS [NATI'L COMMI'N OF FOREIGN INVEST.], INFORME ESTADISTICO SOBRE EL COMPORTAMIENTO DE LA INVERSION EXTRANJERA DIRECCTA EN MEXICO ENERO-DICIEMBRE DE 2007 [STATISTICAL REPORT ON THE BEHAVIOR OF DIRECT FOREIGN INVESTMENT IN MEXICO JANUARY-DECEMBER 2007] (2007), www.economia.gob.mx/pics/pages/1175_base/Dic07.doc. This report states that 17,551 U.S. companies are involved with. foreign investment. This equates to $52.9 \%$ of the total number of companies involved in direct foreign investment registered in Mexico which is 33,209 companies. The American companies mainly conduct their commercial transactions in the areas of services with $44.5 \%$, in the manufacturing industry with $28.4 \%$, and in commerce with $20.2 \%$. They are located principally in Mexico City, Baja California, Baja California Sur and Nuevo León. Id.

71. See id. (showing the U.S. Investment from 1994 through 2007).

72. From January 1999 to September 2006, the United States directed its investments to Mexico as follows: $48 \%$ to the manufacturing industry in maquiladoras located along the border with the United States, $34 \%$ to tourism principally in coastal areas, $12 \%$ to commerce, $5 \%$ to transport and communications, and $1 \%$ to other. See SUBSECRETARIA DE NORMATIVIDAD, INVERSIÓN EXTRANJERA Y PRACTICAS COMERCLALES INTERNACIONALES [UNDERSECRETARY OF STANDARDIZATION, FOREIGN INVEST., \& INT'L COMMERCIAL Practice], Direccion General de Inversión Extranjera [Main Directorate of FOREIGN INVEST.], INVERSION DE ESTADOS UNIDOS EN MÉXICO [INVESTMENT OF THE 
When the Foreign Investment Act of 1993 was formally enacted (after the favorable testing of the "legal waters" was accomplished with the 1989 Regulations to the Foreign Investment Act of 1973), the government of Mexico-and especially the private sector-were strongly in favor of a more modern and flexible policy towards foreign investment. This was especially true in allowing foreign investors to directly own in fee simple vast portions of the Restricted Zone. This policy acted as the most powerful legal magnet attracting U.S. and other foreign investments at that time.

Both the Mexican government and the private sector and the foreign investment countries - for example the United States, the United Kingdom, Germany, Switzerland, France, Japan, and Spain-were pleased to see that the entering into the convenio with SRE gave each foreign investor the dominio, direct ownership in fee simple, over real estate in the Restricted Zone without having to amend the Federal Constitution. Indeed, this was a masterful strategy accomplished by the administration of President Carlos Salinas de Gortari.

Looking into the future, the time may be politically ripe for the new administration of Lic. Felipe Calderón Hinojosa to eliminate the discriminatory treatment against foreigners and foreign companies found in several Articles of the Federal Constitution, including the outright and outdated prohibition that has already exhausted its legal meaning and use found in Article 27, paragraph one.

\section{A. Maximum Duration of the Fideicomisos}

Pursuant to Article 13 of the Foreign Investment Act, fideicomisos have a maximum duration of fifty years and may be renewed at the request of the interested party. In this case, the application must be made through the corresponding fiduciary institution and be submitted to the SRE within the ninety days preceding the termination of the contract. The extension is to be granted provided the original conditions that led to the approval of the fideicomiso subsist or have been complied with, as applicable according to Article 11 of the Foreign Investment Act Regulations. $^{73}$

UNITED STATES IN MEXICO], (2006), http://www.economia.gob.mx/pics/p/p1240/EUASEP06.doc.

73. Ley de Inversión Extranjera [L.I.E.] [Foreign Investment Law], art. 13, Diario Oficial de la Federación [D.O.], 27 de Deciembre de 1993 (Mex.); Reglamento de la Ley de Inversión Extranjera y del Registro Nacional de Inversiones Extranjeras [Foreign Investment Regulations], arts. 11-12, Diario Oficial de la Federación [D.O.], 8 de Septiembre de 1998 (Mex.). 


\section{B. Formalities}

Generally, the parties to the fideicomiso agree that the real estate contract is to be interpreted and complied with in accordance with the applicable Mexican law. This expressly subjecting them to the jurisdiction of Mexican courts in case of controversy. It also renounces any other jurisdiction present or future. In this regard, it is convenient to keep in mind the tenor of Articles $12^{74}$ and 13, paragraph III, of the Federal Civil Code. $^{75}$

Under Mexican law, fideicomiso contracts must be executed by a Notary Public, Notario Público, in order to be valid and produce the corresponding legal effects, as contained in the corresponding public deed or escritura pública. Notaries also play an indispensable official and legal role in the creation and establishment of foreign legal entities in Mexico. ${ }^{76}$

\section{ACQUisition of REAL Estate In THE PERMITTED Zone} following:

In this respect, the Foreign Investment Act prescribes the

Foreigners who intend to acquire real estate outside of the Restricted Zone... shall previously submit to the Secretariat of Foreign Affairs a writing where they agree with what was prescribed by paragraph one of Article 27 of the Federal Constitution [the convenio or cláusula calvo] and obtain the corresponding permit from the Secretariat of Foreign Affairs.

When the immovable asset intended to be acquired is in a municipality which is completely located outside the Restricted Zone ...., the permit is deemed to be granted [afirmativa ficta] if the Secretariat of Foreign Affairs's denial does not appear published in the Diario Oficial de la Federación [or Federal Official Gazette] within the following five working days of the date of submission of the application.

74. Article 12 of the Federal Civil Code enunciates the principle of limited territoriality whereby Mexican laws apply to all persons physically located within the Republic of Mexico, including acts and events which take place within the territory of the Republic. The substance of this Article is found in each and every State Code. For the explicit language, see Código Civil Federal [C.C.F] [Federal Civil Code], as amended, art. 12, Diario Oficial de la Federación [D.O.], 26 de Mayo de 1928 (Mex.); VARGAS, MEX. CIVIL CODE, supra note 20, at 3.

75. Paragraph III of Article 13 of the Federal Civil Code prescribes that, regarding the choice of applicable law, real estate acts are to be governed "by the laws of the place where they are situated" or lex rei sitae. C.C.F. art. 12; VARGAS, MEX. CIVIL CODE, supra note 20 , at 5 .

76. See, e.g., Reglamento de la Ley de Inversión Extranjera y del Registro Nacional de Inversiones Extranjeras arts. 13-20, especially in the establishment of foreign legal entities, personas morales extranjeras, in the preparation of their By-laws, the inclusion of the "Foreigners' Exclusion Clause" (Cláusula de Exclusión de Extranjeros) and the "Clause for the Admission of Foreigners" (Cláusula de Admisión de Extranjeros). See infra pt. VI.A. 


\begin{abstract}
When the immovable asset intended to be acquired is in a municipality which is partially located within the Restricted Zone, the Secretariat of Foreign Affairs shall resolve the petition within the following thirty days following the date of its submission.

The National Institute of Statistics, Geography and Information [or Instituto Nacional de Estadística, Geografia e Informática or INEGI] shall publish in the Diario Oficial de la Federación and shall maintain an updated list of the abovementioned municipalities, as well as those which are located totally within the Restricted Zone.

The Secretariat of Foreign Affairs may determine, through general agreements to be published in the Diario Oficial de la Federación, [certain agreed conditions] whereby foreigners, to have the right to which this Article refers to, may only have to submit before said Secretariat a writing [or escrito] in which they agree with what is prescribed by paragraph one of Article 27 of the Federal Constitution, without requiring the corresponding permit from the Secretariat of Foreign Affairs. ${ }^{77}$
\end{abstract}

This Article adds that INEGI shall publish in the Diario Oficial an updated list of the municipalities that are either totally or partially located within the Restricted Zone. ${ }^{78}$ Regarding leasing of real estate property in the Permitted Zone that is, outside the Restricted Zone, the SRE permit is not required for individual foreigners or for foreign legal entities, including Mexican companies with the Admission of Foreigners Clause.

\title{
A. Sanctions in Case of Violations
}

Articles 38 and 39 of the Foreign Investment Act of 1993 impose sanctions for violations committed against the Act and its 1998 Regulations, independent of the resulting civil and criminal liability. These are some of the sanctions:

I. When the foreign investment is devoted to certain activities, real estate acquisitions, or any other act requiring the express authorization of the National Commission of Foreign Investments or Comisión Nacional de Inversiones Extranjeras, ${ }^{79}$ without

77. L.I.E. art. 10-A (emphasis added).

78. See, e.g., Primera Lista de municipios y delegaciones totalmente ubicados fuera de la zona restrigida que señala la fracción I del artículo 27 Constitucional 27 [List of Municipalities and Delegations Located Totally Outside the Restricted Zone as Indicated by Paragraph 1 of Article 27 of the Constitution], Diario Oficial de la Federación [D.O], 27 de Mayo de 1997 (Mex.).

79. L.I.E. arts. 23-30 (detailing the functions of the National Commission of Foreign Investments). 
having obtained the proper authorization, a fine ranging from one thousand to five thousand salaries shall be imposed ${ }^{80}$

II. In the case of omission, delayed compliance, incomplete or incorrect information regarding obligations to register, report or inform the National Registry of Foreign Investments by foreign nationals or foreign legal entities, a fine ranging from one hundred to three hundred minimum wages shall be imposed;

III. In the case of simulated acts with the purpose of allowing the enjoyment or disposition of real estate in the Restricted Zone to foreign individuals or foreign legal entities, or to Mexican companies with the Admission of Foreigners Clause, in contravention of the Foreign Investment Act (Titles Second and Third), the violator shall be sanctioned with a fine up to the total amount of the legal transaction; and

IV. In any other cases involving violations to the 1993 Foreign Investment Act, or its Regulations, the fine shall range between one hundred and one thousand minimum wages. ${ }^{81}$

There is a special hearing held by the Secretariat of Economy where the alleged violator can be heard and evidence can be presented, Additionally, in cases involving the imposition of monetary sanctions, the Secretariat of Economy must "take into consideration the nature and seriousness of the violation, the economic capacity of the violator, the time elapsed between the date when the obligation had to be complied with and its eventual compliance, and the total value of the transaction." of Economy is the only official entity empowered to impose sanctions pursuant to the Foreign Investment Act. ${ }^{83}$ The proceedings are controlled by the 1998 Foreign Investment Act Regulations and by the Federal Act of Administrative Procedure or Ley Federal de Procedimiento Administrativos. ${ }^{84}$

80. The minimum wage, salario minimo, in the Federal District, Mexico City, is to be used as the amount to be multiplied by the corresponding sanction. For example, the minimum wage in Mexico City in December 2006 was equivalent to $\$ 6$ dollars. If it were multiplied by 1000 , it would result in a $\$ 6000$ fine.

81. L.I.E. art. 38.

82. Id.

83. Id.

84. Ley Federal de Procedimiento Administrativo [L.F.P.A.] [Administrative Procedure Law], as amended, Diario Oficial de la Federación [D.O.], 4 de Augusto de 1994 (Mex.). This federal statute controls the entirety of the internal procedure within the Secretariat of Economy, from the filing of the initial complaint to the final decision and the eventual internal appellate procedure or revisión. Id. 


\section{OTHER CONSIDERATIONS}

\section{A. Required Involvement of a Mexican Notary Public}

The Mexican Public Notaries cannot be compared with the individuals called "Public Notaries" in the United States. In Mexico and other civil law countries,, Public Notaries are highly competent and specialized private attorneys whose professional legal services are indispensable and mandated by the applicable law in the conduct of certain important legal acts. This is especially true in real estate transactions, transfers or conveyances of property, issuance of land titles, the establishment and incorporation of Mexican legal entities domestic and foreign, and in general as the authenticator of legal acts - to mention but a few.

Notarios Públicos are commonly referred to as "the attorneys' attorney" in Mexico because of their highly specialized legal expertise. In order to be admitted as a Notario, an attorney must have many years of practical experience and then pass a difficult and technical legal examination. ${ }^{85}$

Both the Foreign Investment Act of 1993 and its 1998 Regulations impose specific obligations on Public Notaries in the conduct of their professional services involving fideicomisos, real estate transactions, and the constitution and modification of foreign legal entities. Any time a Notario Público is to formulate a fideicomiso contract, for example, it has to verify the identity of the parties involved; the correct legal status of any foreigners involved in the transaction; the validity of the authorizations and permits issued by the SRE; that the convenio mandated by Article 27, paragraph one, of the Federal Constitution has been entered into; that the real estate in question has no liens or other encumbrances; the correct demarcation of the real estate; the proper payment of state and federal taxes; the recording of the Property Title at the respective Public Registry of Property and Commerce or Registro Público de la Propiedad y del Comercio; and the recording of the transaction at the National Registry of Foreign Investments Registro Nacional de Inversiones Extranjeras, among other things.

Above all, the Notario Público must ascertain that the transaction in question is in full compliance with the applicable Mexican law and in accordance with the public interest of the Nation, as mandated by the pertinent federal and state statutes and regulations. When the Notario Público detects any anomalies, such as the lack of a proper visa of a

85. See VARGAS, supra note 15 , at 15-17. 
foreign national to validly execute the transaction in question or the lack of payment of taxes, in his or her capacity as a semi-government official, the Notario must immediately report the defects or anomalies to the proper Mexican authorities.

The Foreign Investment Act and other applicable state and federal statutes impose severe sanctions to Public Notaries when they engage in inappropriate transactions or in negligent professional services. ${ }^{86}$

\section{B. The Federal Maritime Land Zone}

Mexico is endowed with beautiful coastlines along the Baja California peninsula in the Pacific Ocean, the Gulf of California, the Gulf of Mexico and the Caribbean Sea, longer than seven thousand miles, some $10,000 \mathrm{~km}$. In fact, it has the longest and most varied coastlines in Latin America. However, pursuant to Article 42 of the Federal Constitution, Mexico's national territory comprises the continental land mass, the adjacent islands, the submarine continental shelves, as well as the maritime internal waters and those of the surrounding territorial seas, with the width and legal characteristics prescribed by the applicable international law. All of this land belongs to the Nation, under its exclusive sovereignty and ownership and is inalienable. Neither a Mexican nor foreigner national nor legal entity can utilize or exploit these areas unless the corresponding permits, authorization, or concessions are granted by the competent Mexican authority and in accordance with Mexican law. ${ }^{87}$

Accordingly, under Mexican Public Law, the coasts and beaches in the Republic of Mexico are defined as national assets or bienes nacionales ${ }^{88}$ subject to a common use legal regime, bienes de uso común. ${ }^{89}$ In other words, these assets are free and open to everyone for common use. No one has the right to own them or to appropriate them because they belong to the Nation, and only the Nation can use or dispose of them. In this regard, Article 7 of the General Act of National Assets states that assets of common use are: "The maritime beaches, to be understood as the land areas which the tides covers and uncovers with water, from the boundaries of the annual highest tide to the lowest tide ... [and] [t]he federal maritime

86. See, e.g., L.I.E. art. 39; Reglamento de la Ley de Inversión Extranjera y del Registro Nacional de Inversiones Extranjeras [Foreign Investment Regulations], arts. 45, 49, Diario Oficial de la Federación [D.O.], 8 de Septiembre de 1998 (Mex.).

87. Constitución Política de los Estados Unidos Mexicanos, as amended, art. 27, Diario Oficial de la Federación [D.O.], 5 de Febrero de 1917 (Mex.).

88. See Ley General de Bienes Nacionales [L.G.B.N] [General Act of National Assets], Diario Oficial de la Federación [D.O.], art. 3, 20 de Mayo de 2004 (Mex.). The Secretariat of the Public Function or Secretaria de la Función Pública exercises exclusive jurisdiction and control over these national assets.

89. Id. art. 7 (relative to bienes de uso común). 
land zone" or zona federal marítimo terrestre. ${ }^{90}$ The same federal Act prescribes that "[A]ll the inhabitants of the Republic may use the common use assets, with no restrictions [other] than those established by the administrative laws and regulations. A concession, authorization or permit is required for the special utilization of these assets to be granted with the conditions and requirements established by the laws." $" 91$

In other words, marine coastlines and beaches in Mexico, including the Federal Maritime Land Zone, belong to the federal government. No person, physical or legal, domestic or foreign, can use, utilize, exploit, possess or otherwise directly or indirectly own said coastlines and beaches or erect walls, fences or obstacles that may obstruct or impede the free access of people to the coastlines and beaches. Therefore, there are no "private beaches" anywhere in Mexico. Additionally, no private beaches or coastal private clubs are to tolerated if they obstruct or impede the free flow of people to any coastline or beach in the Federal Maritime Land Zone, the Republic of Mexico, or any of its islands. The Federal Maritime Land Zone is defined by the General Act of National Assets in these terms "Both in the continental land mass and in the islands forming a part of the national territory, the Federal maritime land zone shall be determined: Along the coastline with beaches, the Federal Maritime Land Zone is the land belt of twenty meters in width, open to transit and contiguous to said beaches." 92 Finally, the same Federal Act states that the Secretariats of the Environment and Natural Resources (Semarnat), of Communications and Transport (SCT), and of Tourism (Sectur) within the ambit of their legal attributions shall coordinate among themselves in order to promote the construction and operation of specialized infrastructure along the shores. ${ }^{93}$

So, when an American company invests, for example, in the construction of a luxury hotel with adjacent condominiums, shopping centers, and restaurants, and a golf course and a marina, that company must file a petition to the Secretariat of Tourism or Semarnat to obtain a permit or authorization to be able to use the FMLZ contiguous to the hotel for tourism and other commercial purposes. In general, Semarnat conducts the necessary environmental studies, Environmental Impact Statement or EIS, to determine the viability of the project from an
90. Id
91. Id. art. 8.
92. Id. art. 119.
93. Id. art. 123. 
environmental viewpoint. The SCT intervenes to survey the area and establish the respective boundaries, measurements and demarcations for the location of the FMLZ, and Tourism controls the domestic and international commercial tourism aspects.

Assuming the EIS is finally approved by Semarnat, and is coordinated with Sectur and SCT, a federal permit or authorization is granted. Obtaining these permits imparts considerable cost on the American company ${ }^{94}$ who owns the hotel. This is because of the length and location of the FMLZ, the types of uses and services, the size of the hotel and other commercial constructions, and pollution impacts, among other things. The permits or authorizations are generally granted for a specific number of years $(5$, 10,25 , etc.), for specific uses, under certain conditions, and with a specific cost.

The federal government, through the respective Secretariat(s), is empowered to conduct periodic visits and inspections to monitor compliance by the foreign legal entity with the respective permit and the corresponding conditions, if any. If there is a violation of the permit, or to any other applicable statute or regulation, the permit holder may be sanctioned by the pertinent federal agency with fines or even imprisonment. ${ }^{95}$

It should be emphasized that pursuant to the General Act of National Assets, any works, constructions, or installations erected upon any kind of federal real estate properties including the FMLZ without permit, authorization or contract, will be lost to the benefit of the Federation. If this occurs, the Secretariat of the Public Function will order that the works or installations be demolished at the violator's expenses, with no indemnification or compensation. ${ }^{96}$

\section{Questionable Validity of Article 27 Permit Under International Law}

The imposition to foreigners and foreign legal entities of the convenio mandated by Article 27, paragraph one, of the Federal Constitution, historically traces its origin to the so-called calvo clause, cláusula calvo, attributed to the Argentinean jurist Carlos Calvo ${ }^{97}$ in the 19th century. In general, this clause is a stipulation inserted in a contract between a government and a foreign national or foreign legal entity whereby the

94. Id. art. 127

95. Id. arts. 149-50.

96. Id. art. 151. This federal statute imposes most severe sanctions on the Public Notaries who authorize legal acts in contravention of the statute and its regulations. See id. art. 152.

97. See Carlos Calvo, Derecho internacional teórico y práctico de Europa Y AMERICA [INTERNATIONAL LAW IN THEORY AND PRACTICE] (1868). 
latter agrees to be legally treated as a national of the host country, promising not to seek the diplomatic assistance or protection of his or her government in any controversy or claim of or in connection to the contract.

Whereas the original clause was intended to apply to the investments made by foreigners in a given country, Mexico applied it as a conditio sine qua non to foreign nationals or foreign legal entities when acquiring real estate in that country, especially in the Restricted Zone. Indeed, this was the clear intention of the 1916-17 Constitutional Congress when it included the obligation imposed to be on foreigners entering into the convenio mandated by Article 27 of the Federal Constitution. However, it is unquestionable that international law and the bilateral relations between Mexico and the United States were dramatically different in 1917 when the Constitution was enacted. The current political, legal and commercial climate between these two countries in the 21 st century is quite different.

Today, international law is overwhelmingly in favor of recognizing that a foreign national or foreign legal entity cannot validly enter into an agreement, convenio, with a third State, say, Mexico, and renounce certain fundamental and inalienable rights. These rights, such as the right to have a fair trial, due process, the right to have a nationality, and the right to be protected in a legal, political and diplomatic manner by the State of their nationality, simply cannot be waived, suppressed or renounced when they have been breached, diminished, or violated by a third State. It would be absurd, for example, if Mexico were to impose an obligatory condition upon foreigners (such as Americans, Guatemaltecos, Salvadoreños, and others) to sign a convenio renouncing any indemnification or compensation if their lawfully acquired ranch or house in Mexico is expropriated by the Mexican government for reasons of public interest. It would likewise be unlawful if the U.S. government would impose on lawful Mexican immigrants the obligation to sign an agreement renouncing the protection of the Mexican Consul when their constitutional or human rights are violated in this country.

In fact, Chapter XI of NAFTA and the enactment of the Foreign Investment Act of 1993 clearly show a welcome liberalization of the legal regime governing foreign investment in Mexico. These legal developments have been validly interpreted by modern Mexican 
specialists ${ }^{98}$ as a new legal philosophy that from a substantive viewpoint do away with the unfair content of the obsolete calvo clause. They also argue that today the clause has become nothing more than a legal relic.

Hopefully, in symmetry with the new legal philosophy of the current Foreign Investment Act and with the globalization phenomenon affecting the relations between these two countries, Mexico will do away with the heavy historical and political baggage that it has imposed upon foreign investment. As both countries move forward in the 21 st century, it may not be long before Mexico is ready to enact a new and more liberal legal regime for foreign investment-modern, democratic and fair-that would contribute to closer and friendlier relations with the United States.

\section{CONCLUSIONS}

Currently, Mexico's legal regime controlling investment, including the acquisition of real estate by foreigners and foreign legal entities, relies on a cumbersome, costly, and complicated process. The Foreign Investment Act of 1993 and its 1998 Regulations represent a more progressive and liberal regime, compared to the 1973 Foreign Investment Act. However, economic and legal developments fueled by the globalization process strongly suggest that Mexico will produce a new legal framework that promotes and protects foreign investment flowing into the country.

Decidedly, the calvo clause, the limitations inherent in the Restricted Zone, and of the convenio imposed upon foreigners by Article 27 of Mexico's Federal Constitution, have outlived their original purpose. The geographical contiguity of the United States to Mexico, and the growing interactions between both countries based not only on geography but, more importantly, on people and wealth considerations, ${ }^{99}$ lead to the inescapable conclusion that a more liberal and progressive legal framework governing the acquisition of real estate by foreigners and foreign legal entities is necessary. Such a new foreign investment framework must be but a part of an overall modern and progressive legal regime on foreign investment in Mexico. The regime should share the liberal philosophy of the Foreign Investment Act of 1993 and further advance its flexibility and fairness. It should do so in consonance with the globalization phenomenon, the modern principles of economic international law and, in particular, the

98. See Miguel RÁbago DorbeCKER, DERECHO DE LA INVERSIÓN EXTRANJERA EN MÉXICO [MEXICO'S FOREIGN INVESTMENT LAW] 281-300 (2004). It was not until 1997 when this legal discrepancy was pointed out. See Leonel Pereznieto Castro, Dos Mitos en el Derecho Internacional Privado: la Cláusula Calvo y la Zona Prohibida o Zona Restringida, in 2 Revista Mexicana de DeRECho InTERnacional PRIVADo 111-34 (1997).

99. See Jorge A. Vargas, An Introductory Lesson to Mexican Law: From Constitutions and Codes to Legal Culture and NAFTA, 41 SAN DIEGO L. REv. 1337 (2004); Vargas, supra note 27. 
prospects for a more sound and close relation between Mexico and the United States. The new foreign investment regime should make no distinctions between Mexican and foreign investments nor divisions of the Mexican territory into Restricted and Permitted Zones. 
